How to cite this article:

Ibrahim, N. (2020). Social support among elderly in institutions: Towards healthy aging. Jurnal Pembangunan Sosial, 23, 129-143. https://doi.org/10.32890/jps2020.23.8

\title{
Social Support among Elderly in Institutions: Towards Healthy Aging

\author{
(Sokongan Sosial dalam Kalangan Warga Emas \\ di Institusi: Ke Arah Penuaan Sihat)
}

\author{
NABISAH IBRAHIM \\ Pusat Pengajian Psikologi Gunaan, \\ Dasar dan Kerja Sosial \\ Universiti Utara Malaysia \\ nabisah@uum.edu.my
}

Received: 9/2/2020 Revised: 7/6/2020 Accepted: 23/12/2020 Published: 30/12/2020

\begin{abstract}
This paper aims to discuss the importance of social support in developing healthy aging among elderly in institutions. It covers a discussion on the factors that are required to define the availability of social support for the elderly and what kinds of support systems needed in order to maintain healthy aging. Realizing about the limitation of support system available for elderly in institutions, this paper also includes the discussion on factors that inhibits social support among this marginal group and provides strategies and intervention on how to enhance the availability of social support for this population.
\end{abstract}

Keywords: Social support, elderly in institutions, healthy aging.

\section{Abstrak}

Makalah ini bertujuan membincangkan tentang kepentingan sokongan sosial bagi membina penuaan sihat dalam kalangan warga emas di 
institusi. Ianya merangkumi perbincangan mengenai faktor-faktor yang diperlukan untuk menentukan keberadaan sokongan sosial dan jenis sistem sokongan yang diperlukan untuk mengekalkan penuaan sihat. Menyedari tentang keterbatasan sistem sokongan sedia ada bagi warga emas di institusi, makalah ini juga merangkumi perbincangan mengenai faktor-faktor yang menghalang kumpulan marginal ini mendapatkan sokongan sosial dan turut memberikan strategi dan intervensi bagaimana meningkatkan sokongan sosial dalam kalangan populasi ini.

Kata kunci: Sokongan sosial, Warga Emas di institusi, penuaan sihat.

\section{Introduction}

We all aspire to a healthy old age. This goal has been portrayed through an increased number of researches with older population to promote healthy aging (Price \& Sanford, 2012; Tohit et al., 2012; Masotti, Fick, Johnson-Masotti \& Macleod, 2006). Healthy aging as defined by Center of Healthy Aging (2012) refers to a process of taking charge of your own well-being, as you grow older. It is believed that by taking charge, elderly will be able to reduce the risk of disease and related disability, function well physically and mentally, and be actively involved in life activities.

Researchers have come out with different steps that individuals especially elderly can take to achieve and maintain healthy aging. First, educate yourself with knowledge that could encourage you to maintain good health as your priority. Second, get expert care and support when you need it, for example; a medical support from your doctors or therapeutic support from your counselors. Third, stay independent by doing as much as you can for yourself because research mentioned that elderly who have high level of autonomy have higher self-efficacy and self-esteem than elderly who depend on others (Backman \& Hentinen 2001). Fourth, keep yourself strong by doing regular exercise because research showed that regular exercise does promote healthy aging and slows down the effects of aging in the elderly (Danielle, 2016). The fifth step is to stay connected with others and get support when needed. Even though all the aforementioned steps are necessary for elderly to 
maintain healthy aging, social support and social networking has been found to provide greater effect on the life of elderly as compared to other age categories in the stages of human development (Wilby, 2011). Therefore, it is important to understand how social support could promote healthy aging, especially among elderly in institutions.

\section{What is Social Support?}

The words social support and social network have been used interchangeably. Social network has been consistently defined in several researches (Al-Kandari, 2012; Wilby, 2011; Thanakwang \& Soonthorndhada, 2011) as a number of contacts that individuals have in their lives, which may include their family members, friends, relatives, and colleagues. Social support, on the other hand, refers to the perceived and actual assistances that individuals could get and are available for them when they need it, which may or may not come from their social network (Pfeil et al., 2011). Besides the aforementioned meaning, the term social support is also referred to as individuals' quality of lives, behaviors, relationship with others and connection that they have with their social institutions (Veiel \& Baumann, 1992).

Different scholars have different ideas in discussing about the division of social support. Veiel and Baumann (1992) divided social support into two main aspects known as structural and functional aspects. Structural aspect of social support refers to a connection among individuals, while the functional aspect of social support refers to the actual resources received from that connection, for example when an elderly received monthly financial assistance from his or her children. Sarason and Sarason (2009) categorized social support into three aspects and they are, sources of social network, received social support, and perceived social support. They argued that it is very important for researchers to identify what types of social support that they really want to measure in their elderly participants. If the researchers want to measure the social support received by the elderly, they need to measure the actual behaviors, attitudes, or emotions that the elderly received from his or her social circle. If the researchers intend to measure the perceived social support, then they need to measure how much support that the elderly perceived they get from their support 
providers. In order to consider whether an individual has social support or not, Hupcey (1998) proposes five factors that are required to define the availability of social support. The factors are as follow:

a. The behavior of providing a resource when it is needed.

b. The social support receipient having a sense that he or she is being cared for or what we call as having a sense of well-being.

c. Relationship exists between the provider and the recipient of that support or resource.

d. Support not given from or to an organization, the community, or a professional, and

e. Support does not have any negative intention or is given unwillingly.

Based on the above factors that are required to define availability of social support, it can be clearly observed that elderly in institutions need to have other types of social support that are available for them outside of their daily care support system given by their institutions. The social support may come from their family, relatives, and friends. Studies show that strong support from family, relatives and friends promotes healthy aging among elderly adults (Al-Kandari, 2011, Gardner, 2011; Litwin, 2010).

\section{Social Support and Healthy Aging}

Need for others is a part of individual's developmental necessity. As individuals grow older, they would go through the negative effects of aging process. They may experience more physical challenges to perform daily life activities, loss of financial resources as a result of retirement, and experience more grief and bereavement due to death (Himes, 1992; Newman, \& Newman, 2006). In order to face all these living limitations, the elderly people need to be convinced that they are living in a social network where they are valued and cared for. They need to know they have social support that appreciate and need them (Al-Jawad, Rashid, \& Narayan, 2007; Himes, 1992).

Social support is found to be one of the environmental needs of elderly in institutions that need to be fulfilled in order to achieve healthy aging life (Rigby et al., 2010). Unfortnately, not all elderly people are 
lucky to have social support later in life. This is because, for some elderly people, their social support may be lessened and diminished when their significant others such as spouse, family, and friends passed away (Chu \& Chow, 2008; Choi \& Wodarski, 1996). The loss of significant people together with other types of loss (i.e. physical deteriorations) have found to be factors that contribute to higher level of isolation especially among the elderly women (Liu \& Richardson, 2012; Rigby et al., 2012). There is a relationship between perceiving social support and mortality in older elderly when it provides protective function with regard to different health issues. Older adults with fewer social resources were at high risk for depression and suicidal ideation (Choi \& Wodarski, 1996).

Additionally, researchers have reported that there are an increase number of morbidity and mortality cases among the elderly women who have lack of social support (Le Lebowitz et al., 2019). In contrast, elderly adults who received adequate social support from spouse, family, or friends are found to be healthier than those who received lower social support (Khami et al., 2020; Choi \& Wodarski, 1996; Yang et al., 2019).

The elderly social support may come from their family, relatives, friends, or social workers. Previous study shows that family support plays an important role in the life of elderly adults. Al-Kandari (2011) found that support from family can alleviate hypertension. Hypertension is defined as a blood pressure over $140 / 90 \mathrm{~mm} \mathrm{Hg}$ and it affects more than two out of three individuals over 75 years of age. Persons with more social support are relatively unaffected by stress. On the other hand, persons with high stress and no social support have much higher blood pressure that can eventually lead to hypertension. In the same study conducted by Al-Kandari (2011), the researcher also found that there is a direct relationship between the number of children who live with elderly adults in the same household and lower health problem. The researcher concluded that the more children or offspring living together with their parents or elderly adults, the better the elderly feel and less problems they have with hypertension. Other research shows that married elderly adults were healthier compared to unmarried elderly adults (Winner \& Tilly, 2012). This finding could indicate that social support that the elderly adults receive from their spouses does affect their health. 
Recent studies indicated that social support especially from the family has been found to be a factor of resilience for all elderly people and the activity and social involvement of elderly provides meaning in life and acts as a potential resistance factor towards suicidal tendencies among elderly living in institutional settings (Cohen-Louck, \& AviadWilchek, 2020). In 30 years, researches consistently found that friends are more socially important to older adults than their family members. Friends were found to have a more positive impact on relieving depression and loneliness of institutionalized older adults than family members (Mullins \& Dugan, 1990; Soimah, \& Hartiani, 2020). The result logically represents the pattern of social support among the institutionalized elderly population who no longer live with their family and are spending more times with their friends in the institutions. Regardless of how much the elderly adults in institutions receive social support from either their families or friends, satisfaction with support provided to them is found to be a more important predictor of depression levels than other objective measures of network relationships (Soimah, \& Hartiani, 2020; Wilby, 2011).

\section{Studies on Social Support among Malaysian Elderly}

In Malaysia, social support has been viewed as a potential correlate of elderly's mental health. Elderly who receive lower social support tend to experience higher social isolation, which later on leads to depression. Feeling empty, alone and unwanted due to social isolation has been considered as part of loneliness. It has long been known that loneliness has a strong connection with depression, which affect mental health among elderly population (Lara et al., 2020; Li, Jiang, \& Zhang, 2019).

Wan Mohd Azam and colleagues (2013) conducted a crosssectional study to find out whether social support acts as a mediator in relation to loneliness and depression among elderly population. One hundred and sixty-one community dwelling elderly in the rural area of Sungai Tengi, Malaysia participated in the survey. Results showed that social support has a mediating effect in the relationship between loneliness and depression. Even though the results showed only partial mediating effect, the researchers concluded that social support available to elderly population could reduce the negative effect of loneliness on depression. 
Another study was undertaken in continuation of the previous one, on the same elderly population (Ibrahim, et. al., 2013). One hundred and sixty-two elderly aged 60 years and above, who reside in rural areas of Federal Land Development Authority (FELDA) Sungai Tengi participated to measure the association between social support and depression and to predict the elderly quality of life. The outcome of this study indicated that there is a significant association between elderly's social support and their quality of life. Elderly who have more social support were reported to have higher quality of life than those who have less social support.

The result also showed that there is a negative association between elderly social support and level of depression. The less social support they have, the more depressive symptoms they have reported in this study. The percentage that has mild depression was only about 23.5 percent while 2.5 percent of the participants who reported to have less support suffered from severe depression. The researchers concluded that the high quality of life of these elderly was a positive indication of their psychological well-being and that social support in the form of emotion and information, and depression were two factors that significantly related to their good life quality (Ibrahim et. al., 2013).

The availability of social support for elderly population is not only crucial for their better life quality, but also to maintain their morale. It is understood that a person who has a high spirit or morale is happy, confidence, positive and optimistic (Şahin et al., 2019). On the other hand, a person who has low spirit or morale is unhappy, lack or no confidence, negative and pessimistic. It is believed that low morale may lead to a detrimental psychological consequence, such as low selfesteem and high level of stress (Matud, \& García, 2019).

Health related quality of life can be divided into two aspects; physical and mental. The quality of these two components has been measured in relation to the level of social support along with other predictive factors with 347 Malaysian elderly aged 55 years and older with non-communicable diseases (Sazlina et al., 2012). The study took place at three publicly owned primary care clinics in Selangor, Malaysia. The findings reported that people who increase in age, being single, have two morbidity conditions and poorer social support were predicted to have lower physical health. Also, the researchers reported 
that older women, Indian descent and poorer social support were predictors of lower mental component.

\section{Factors Inhibit Social Support among Elderly in Institutions.}

Not everybody is fortunate enough later in their life to have social support. This is because, for some of them, their social support may be decreased and reduced as their significant others such as their spouse, relatives and friends, passed away (Chu \& Chow, 2008; Choi $\&$ Wodarski, 1996). There are several factors that may inhibit social support among elderly, especially those who lives in elderly institutions.

\section{Mistrust}

Mistrust is a situation when people do not trust anybody and it is identified as the main barrier of social support with elderly. Mistrust can inhibit elderly residents in institutions from reaching out for social support. Several reasons have been identified to have caused mistrust in elderly and among them are aging itself, past traumatized experiences, and problematic personal relationships (Smith \& Rosen, 2009).

As people grow older, the more the experience they gain. Various life experiences especially the negative ones with self, family and friends have an impact on them as they grow old. Experience of death of loved one, difficult interactions with people close to them can create mistrust in them. Because of mistrust, older people would rather refuse to use, maintain or expand their social support.

\section{Self-Isolation}

Previous research reported that elderly people are more likely to suffer self-isolation because of the changes of life, loss of loved ones, and the experience of physical and cognitive function deterioration. Changes in the social environment can also cause loneliness among the elderly. According to (Merchant et al., 2020) an important factor that can plunge into the self-isolation among the elderly is the death of a spouse, depression, and lack of friend.

In addition, some research found that self-isolation among the elderly in institutions may be due to the lack of trust with people 
around them. In the same research by Smith \& Rosen (2009), it was found that mistrust has led the elderly to isolate themselves and refuse to use, maintain or even create new relationships. In addition, the loss of significant people together with other types of loss (i.e. physical deteriorations) have found to be factors that contribute to higher level of isolation especially among the elderly women (Liu \& Richardson, 2012; Rigby et al., 2010).

\section{Disruption of Marital Relationship}

Bad marital relationship is another factor that could prevent elderly from seeking and enhancing social support. The experience of disruption in personal relationship with the spouse could affect the formation of new relationship. The elderly who felt hurt or betrayed due to the bad relationship in the past began to mistrust others thus prevented them from seeking or maintaining social support (Smith \& Rosen, 2009).

\section{Strategies and Interventions to Enhance Social Support among Eldery in Institutions}

\section{Online Support}

Telephone networks and the Internet can be used to enhance social supports available to elderly patients. Counselors and social workers may work with volunteers to befriend socially isolated elderly individuals over the telephone. This intervention may enhance the elderly's level of social support. Cattan et al. (2011) reported that telephone befriending helped improve the independence and confidence of isolated elderly individuals and develop their self-respect, which may lead to better participation and more meaningful relationships.

\section{Video Conference Program}

Video conference program with family members is one strategy that can be used to enhance social support among the elderly. Counselors might also consider incorporating other technologies to enhance social support for the elderly. At one institution, videoconference programs (e.g., Skype) that allow the elderly to speak with family members 
reduced symptoms of depression and loneliness and enhanced social support for the elderly (Tsai et al., 2010).

\section{Psychotherapy Group}

In dealing with elderly who have issues with mistrust and self-isolation, psychotherapy group would be useful. Cattan et al. (2005) found that psychotherapy group or any group-based intervention such as social support group and rehabilitation group where members can influence the content of the intervention are the most effective in alleviating loneliness, mistrust and isolation among elderly.

Practitioners such as counselors, social workers, caretakers, and institutional administrators may want to consider conducting psychotherapy group that increase social support and self-esteem among institutionalized elderly women. Such group may include social skills teaching and activities that would enhance development of friendships, positive socialization, and integration. At the end of group session and activities, practitioners may consider soliciting feedback from participants on the group's effectiveness.

\section{Instilling Sense of Belonging}

Instilling sense of belonging has been found to be one way to reduce feeling of solation among the elderly in institutions. Park et al., 2020) suggest that developing elderly's sense of belongingness would reduce their feeling of isolation and loneliness. Counselors, social workers or caretakers at the instituitons need to encourage the elderly to participate in group activities that not only connect them with other seniors, but at the same time develop their sense of belonging to the group.

Having social support from family and friends contributes to the elderly's sense of belonging and well-being in several ways. Social support helps to protect the elderly from the negative effects of physical deterioration, cognitive decline, and psychological problems (Al-Kandari, 2011; Choi, 1996). It helps them change their reactions toward the aging process and enhance their ability to cope with agerelated changes (Merchant et al., 2020). 


\section{Conclusion}

With the increased number of elderly population, the betterment of the quality of lives of this graying population is one of our prioritized objectives. Knowing about the benefits of social support to elderly adults, the creation and increase of social support resources for elderly adults, especially who do not have quality social support should be emphasized. Sources that provide elderly with social support should be quantitatively or qualitatively increased in order to support and promote healthy aging among elderly population.

\section{Acknowledgment}

This research received no specific grant from any funding agency in the public.

\section{References}

Al-Jawad, M., Rashid, A. K., \& Narayan, K. A. (2007). Prevalence of undetected cognitive impairment and depression in residents of an elderly care home. Medical Journal of Malaysia, 62(5), 375-379.

Al-Kandari, Y. (2011). Relationship of strength of social support and frequency of social contact with hypertension and general health status among older adults in the mobile care unit Kuwait. Journal of Cross-Cultural Gerontology, 26(2), 175-187.

Backman, K., \& Hentinen, M., (2001). Factors associated with the self-care of home-dwelling elderly. Scandinavian Journal of Caring Sciences, 15(3), 195-202.

Cattan, M., White, M., Bond, J., \& Learmouth, A. (2005) Preventing social isolation and loneliness among older people: A systematic review of health promotion activities. Aging and Society, 25, 41-67.

Cattan, M., Kime, N., \& Bagnall, A. (2011). The use of telephone befriending in low level support for socially isolated older people - an evaluation. Health \& Social Care in The Community, 19(2), 198-206. 
Choi, N. G., \& Wodarski, J. S. (1996). The relationship between social support and health status of elderly people: Does social support slow down physical and functional deterioration? Social Work Research, 20(1), 52-63.

Choi, N. S. (1996). The relationship between social support and health status of elderly people: Does social support slow down physical and functional deterioration? Social Work Research, 20(1), 52.

Chu, H. C., \& Chow, P. C. (2008). Providing grief counseling to a major depressive elderly widower: A nurse's experience. $\mathrm{Hu} \mathrm{Li}$ Za Zhi, 55(5), 90-96.

Cohen-Louck, K., \& Aviad-Wilchek, Y. (2020). Suicidal tendencies, meaning in life, family support, and social engagement of the elderly residing in the community and in institutional settings. Isr J Psychiatry, 57(1).

Danielle F. (2016). Mental health this holiday and beyond: 4 steps to combat loneliness in seniors. National Council on Aging. https://www.ncoa.org/blog/how-to-fight-loneliness-seniorsthis-holiday/.

Exercise promotes health--and slows aging--in the elderly. (cover story). (1997). Brown University Long-Term Care Quality Advisor, 9(11), 1.

Gardner, P. J. (2011). Natural neighborhood networks - Important social networks in the lives of older adults aging in place. Journal of Aging Studies, 25(3), 263-271.

Himes, C. L. (1992). Future caregivers: Projected family structures of older persons. Journal of Gerontology, 47(1), 17-26.

Hupcey, J. E. (1998). Social support: Assessing conceptual coherence. Qualitative Health Research, 8, 304-318.

Ibrahim, N., Din, N. C., Ahmad, M., Ghazali, S. E., Said, Z., Shahar, S., \& Razali, R. (2013). Relationships between social support and depression, and quality of life of the elderly in a rural community in Malaysia. Asia-Pacific Psychiatry, 5, 59-66.

Khami, L., Motalebi, S. A., Mohammadi, F., Momeni, M., \& Shahrokhi, A. (2020). Can social support predict health-promoting behaviors among community-dwelling older adults? Social Health and Behavior, 3(1), 22.

Lara, R., Vázquez, M. L., Ogallar, A., \& Godoy-Izquierdo, D. (2020). Optimism and social support moderate the indirect relationship between self-efficacy and happiness through mental health in the elderly. Health Psychology Open, 7(2): 2055102920947905. 
Lebowitz, A., Tachikawa, H., Aiba, M., Okamoto, Y., Takahashi, S., Nemoto, K., \& Arai, T. (2019). Post-flood social support networks and morbidity in Jôsô City, Japan. Psychiatry Research, 271, 708-714.

Li, C., Jiang, S., \& Zhang, X. (2019). Intergenerational relationship, family social support, and depression among Chinese elderly: A structural equation modeling analysis. Journal of Affective Disorders, 248, 73-80.

Litwin, H. (2010). Social networks and well-being: A comparison of older people in Mediterranean and Non-Mediterranean countries. Journals Of Gerontology Series B: Psychological Sciences \& Social Sciences, 65B(5), 599-608.

Liu, J. Jr., \& Richardson, P. K. (2012). Successful aging in older adults with disability. OTJR: Occupation, Participation \& Health, 32(4), 126-134.

Masotti, P., Fick, R., Johnson-Masotti, A., \& MacLeod, S. (2006). Community matters in healthy aging. Healthy naturally occurring retirement communities: A low-cost approach to facilitating healthy aging. American Journal of Public Health, 96(7), 1164-1170.

Matud, M. P., \& García, M. C. (2019). Psychological distress and social functioning in elderly Spanish people: A gender analysis. International Journal of Environmental Research and Public Health, 16(3), 341.

Merchant, R. A., Liu, S. G., Lim, J. Y., Fu, X., \& Chan, Y. H. (2020). Factors associated with social isolation in community-dwelling older adults: A cross-sectional study. Quality of Life Research, $1-7$.

Mullins, L. C., \& Dugan, E. (1990). The influence of depression, and family and friendship relations, on residents' loneliness in congregate housing. Gerontologist, 30, 377-384.

Murtaugh, C. M., Kemper, P., Spillman, B. C., \& Carlson, B. L. (1997). The amount, distribution and timing of lifetime nursing home use. Medical Care, 35(3), 204-18.

Newman, M. B., \& Newman, P. R. (2006). Development through: A psychosocial approach ( $9^{\text {th }}$ ed.). Thomson Wadsworth.

Park, I., Veliz, P. T., Ingersoll-Dayton, B., Struble, L. M., Gallagher, N. A., Hagerty, B. M., \& Larson, J. L. (2020). Assisted Living Residents' Sense of Belonging and Psychosocial Outcomes. Western Journal of Nursing Research, 0193945920906181. 
Pfeil, U., Syangstu, K., Ang, C., \& Zaphiris, P. (2011). Social roles in an online support community for older people. International Journal of Human-Computer Interaction, 27(4), 323-347.

Price, J. M., \& Sanford, A. J. (2012). Reading in healthy ageing: The influence of information structuring in sentences. Psychology and Aging, 27(2), 529-540.

Rigby, J. J., Payne, S. S., \& Froggatt, K. K. (2010). What evidence is there about the specific environmental needs of older people who are near the end of life and are care for in hospices or similar institutions? A literature review. Palliative Medicine, 24(3), 268-285.

Şahin, D. S., Özer, Ö., \& Yanardağ, M. Z. (2019). Perceived social support, quality of life and satisfaction with life in elderly people. Educational Gerontology, 45(1), 69-77.

Sarason, I. G., \& Sarason, B. R. (2009). Social support: Mapping the construct. Journal of Social and Personal Relationships, 26(1), 113-120.

Sazlina, S. G., Zaiton, A., Nor Afiah, M. Z., Hayati, K. S. (2012). Predictors of health related quality of life in older people with non-communicable diseases attending three primary care clinics in Malaysia. J Nutr Health Aging. 16(5), 498-502.

Smith, M., \& Rosen, D. (2009). Mistrust and self-isolation: Barriers to social support for older adult methadone clients. Journal of Gerontological Social Work, 52(7), 653-667.

Soimah, S., \& Hartiani, F. (2020, November). The relationship between perceived social support from family, friends, and significant others (nursing home staff) and life satisfaction among elderly nursing home residents. In 3rd International Conference on Intervention and Applied Psychology (ICIAP 2019) and the 4th Universitas Indonesia Psychology Symposium for Undergraduate Research (UIPSUR 2019) (pp. 460-470). Atlantis Press

Thanakwang, K., \& Soonthorndhada, K. (2011). Mechanisms by which support networks influence healthy aging among Thai community-dwelling elderly. Journal of Aging \& Health, 23(8), 1352-1378.

Tohit, N., Browning, C., \& Radermacher, H. (2012). 'We want a peaceful life here and hereafter': Healthy ageing perspectives of older Malays in Malaysia. Ageing \& Society, 32(3), 405-424. 
Tsai, H., Tsai, Y., Wang, H., Chang, Y., \& Chu, H. (2010). Videoconference program enhances social support, loneliness, and depressive status of elderly nursing home residents. Aging \& Mental Health, 14(8), 947-954.

Veiel, H. O. F., \& Baumann, U. (1992). The meaning and measurement of social support. Hemisphere.

Wan Mohd Azam, W. M. Y., Din, N. C., Ahmad, M., Ghazali, S. E., Ibrahim, N., Said, Z., \& Maniam, T. (2013). Loneliness and depression among the elderly in an agricultural settlement: Mediating effects of social support. Asia-Pacific Psychiatry, 5, 134-139.

Wilby, F. (2011). Depression and social networks in community dwelling elders: A descriptive study. Journal of Gerontological Social Work. 54(3), 246-259.

Winner, J. M., \& Tilly, J. (2012). Population ageing in the United States of America: Implications for public programmes. International Journal of Epidemiology, 31(4), 776-781.

Yang, Y., Zhang, B., Meng, H., Liu,D., \& Sun, M. (2019). Mediating effect of social support on the associations between health literacy, productive aging, and self-rated health among elderly Chinese adults in a newly urbanized community. Medicine, 98(16). 